\title{
LIVE LOADS FOR RURAL BRIDGES
}

\author{
Er. Jagat Kumar Shrestha \\ Lecturer, Civil Engineering Department, Pulchowk Campus, Institute of Engineering, Tribhuvan University
}

\begin{abstract}
We find various loading standards for bridges in different countries based on their own contexts. In the context of Nepal, the road bridges have been designed adopting the various codes. Many of the bridges have been designed based on IRC and AASHTO standards. Nepal Road Standard (NRS 2027), has adopted the IRC and AASHTO loadings. The NRS covers loadings for the highway and feeder roads. The standard does not cover the loading standards for rural roads in Nepal. Now we have more than $20,000 \mathrm{~km}$ rural roads.
\end{abstract}

This paper tries to review the live load standards which are being adopted in design of bridges in Nepal and recommend the live loads suitable for the bridges in rural roads specifically for district roads and village roads.

For rural bridges, individual truck loading may be relevant rather than the train of loading. The 24R IRC loading may be an appropriate loading for rural bridges in Nepal. This represents a heavy vehicle plying in rural roads in Nepal.

\section{INTRODUCTION}

In practice a highway bridge is loaded in a very complex way by vehicles of varying sizes and groupings. In order to simplify the design process this real loading is typically simulated by two basic imposed loads - a uniformly distributed load and a knife-edge load - representing an extreme condition of normal usage. The design is then checked for a further load arrangement representing the passage of an abnormal load. The magnitudes of all these loads are generally related to the road classification, the bridge standard requirements and the loaded length of the bridge.

In the context of Nepal, various loadings are being adopted in design of bridges. There are no demarcation in design standards for highway roads and rural roads. Mostly, the standards are being practiced are AASHTO and IRC design standards and the corresponding loadings. Hence review of these documents would be relevant in the context of rural roads in Nepal.

\section{REVIEW OF DOCUMENTS}

\subsection{AASHTO (1996)}

The highway live loadings on the bridges shall consist of standard trucks or lane loads that are equivalent to truck trains.

\section{Standard H Trucks}

The HS loadings consist of a tractor truck with semi trailer. The HS loadings are designated by the letters HS followed by a number indicating the gross weight in tons of the tractor truck. The variable axle spacing has been introduced in order that the spacing of axles may approximate more closely the tractor-trailers now in use. AASHTO defines two types of loadings. The loadings HS20-44 are being practiced in Nepal. 



Figure 1: AASHTO Loading

\section{Lane Loading}

The lane loading is assumed to occupy a width of 10 feet. These loads shall be placed in 12-foot wide design traffic lanes, spaced across the entire bridge roadway width measured between curbs. Fractional parts of design lanes should not be used but roadway widths from 20 to 24 feet shall have two design lanes each equal to one half the roadway width.

Each lane load shall consist of a uniform load per linear foot of traffic lane combined with a single concentrated load so placed on the span as to produce maximum stress. The concentrated load and uniform load shall be considered as uniformly distributed over a 10-foot width on a line normal to the centerline of the lane.

This loading consists of uniform load 640lbs./linear foot of load lane. Concentrated loads of 18,000 lbs for moment and 26,000 lbs for shear calculations are considered.

\subsection{IRC}

IRC specifies different live loads for footpath, kerb and deck.

\section{For Footpath:}

For designing footpath live load considered is $5 \mathrm{kN} / \mathrm{m}^{2}$. (IRC: $6-2000$ )

\section{For Kerbs:}

For kerbs of $0.60 \mathrm{~m}$ or more in width, shall be designed for $5 \mathrm{kN} / \mathrm{m}^{2}$, and for a local lateral force of $750 \mathrm{~kg}$. per metre. (IRC: 6-2000)

\section{For vehicles:}

The bridges classified by IRC, the designed live load shall consist of standard wheeled or tracked vehicles or trains of vehicles. Three classes of loads are normally in practice in Nepal.

\section{IRC class A}

IRC class A is normally adopted on all roads on which permanent bridges and culverts are constructed. (IRC: 6-2000).

The designed live load shall consist of standard trains of vehicles. Nose to tail distance between successive trains shall not be less than $18.4 \mathrm{~m}$. It consists of a wheel load train of a truck with trailers of specified axle spacing and loads. The axle loads are 2.7 Tons, 11.4 Tons, 6.8 Tons and respectively.

\section{IRC Class AA}

This load represents a tracked vehicle (simulating an army tank) of $700 \mathrm{kN}$ or a wheeled vehicle (heavy duty truck) of 400 $\mathrm{kN}$.

\section{Class $70 \mathrm{R}$ loading}

This loading consists of a tracked vehicle of $700 \mathrm{kN}$ or a wheeled vehicle of total load of $1000 \mathrm{kN}$. The track has contact length of $4.87 \mathrm{~m}$, nose to tail length of the vehicle is $7.92 \mathrm{~m}$ and specified minimum spacing of successive vehicle is $30 \mathrm{~m}$.

Wheeled vehicle is $15.22 \mathrm{~m}$ long and has seven axles with the load totaling $1000 \mathrm{kN}$. 
A bogie loading of $400 \mathrm{kN}$ is also specified with wheel loads of each $100 \mathrm{kN}$.

\section{Other Classes}

Beside these classes of loadings, there are 10 other classes of loadings representing track and wheeled vehicles.

Among the other loads, Class 24R consists of 20 ton loading with four wheels 8 tons in front axle and 12 tons in rear axle in $4.27 \mathrm{~m}$ distance. In the same class of loading, 21.2 ton loading consists of six wheels 4.2 tons in front axle, 8.5 tons in intermediate and rear axles. The distance between the front and intermediate axle is $3.96 \mathrm{~m}$ and the intermediate to the rear axle is $1.22 \mathrm{~m}$. The spacing between successive vehicles is $30 \mathrm{~m}$.

\subsection{Nepal Road Standard (2027)}

Nepal Road Standard adopts AASHTO and IRC loadings. The standard is being revised incorporating earthquake, wind and temperature effects. The summary of the loadings is presented in the following Table 1.

Table 1: Nepal Road Standard (2027)

\begin{tabular}{|c|c|c|c|c|}
\hline $\begin{array}{l}\text { S.N. } \\
\text { (1) }\end{array}$ & $\begin{array}{l}\text { Particulars } \\
\text { (2) }\end{array}$ & $\begin{array}{l}\text { NRS-2027 (Existing) } \\
\text { (3) }\end{array}$ & $\begin{array}{l}\text { NRS-2027 (Revision) } \\
\text { (4) }\end{array}$ & $\begin{array}{l}\text { Remarks } \\
\text { (5) }\end{array}$ \\
\hline \multirow[t]{4}{*}{1} & $\begin{array}{l}\text { Loadings: } \\
\text { For special and major bridges: } \\
\text { One lane of class A is considered to occupy } \\
2.3 \mathrm{~m} \text {. The remaining width of carriageway } \\
\text { shall be loaded with } 5 \mathrm{kN} / \mathrm{m}^{2} \text { or one lane of } \\
\text { class } 70 \mathrm{R} \text { or, two lane of class A or, } \\
\text { AASHTO HS: } 20-44\end{array}$ & N.A. & Proposed & \\
\hline & $\begin{array}{l}\text { For other bridges: } \\
\text { IRC class A for single lane and IRC class AA } \\
\text { or IRC class A (two lane) for two-lane traffic. }\end{array}$ & $\begin{array}{l}\text { HS: } 20-44 \text { or IRC class } \\
\text { AA or any other } \\
\text { equivalent loading }\end{array}$ & No change & \\
\hline & c) Footpath load of $5 \mathrm{KN} / \mathrm{m}^{2}$ & N.A. & Proposed & $\begin{array}{l}\text { Superstructure } \\
\text { having footpaths }\end{array}$ \\
\hline & d) Wearing coat $2 \mathrm{KN} / \mathrm{m}^{2}$ & N.A. & Proposed & $\begin{array}{l}\text { For Asphalt } \\
\text { wearing course }\end{array}$ \\
\hline 2 & $\begin{array}{l}\text { Seismic Forces: } \\
\text { According to Indian Standard criteria for } \\
\text { earthquake resistance design of structure IRC- } \\
\text { 6; } 2000 \text { Fses }=\alpha \beta \gamma \mathrm{g} \\
\text { Or, Horizontal load }=0.15 \mathrm{~g} \\
\text { Vertical load }=0.075 \mathrm{~g}\end{array}$ & N.A. & $\begin{array}{l}\text { Adopt horizontal load } \\
=0.15 \mathrm{~g} \\
\text { Vertical }=0.075 \mathrm{~g} \\
\text { Proposed as per } \\
\text { AASHTO }\end{array}$ & \\
\hline 3 & $\begin{array}{l}\text { Wind Load: } \\
\text { Wind load according to AASHTO } 1977 \\
\text { corresponding to a service load of about } \\
2.40 \mathrm{KN} / \mathrm{m}^{2} \text { (for girders) and } 3.60 \mathrm{KN} / \mathrm{m}^{2} \text { (for } \\
\text { trusses) }\end{array}$ & N.A. & $\begin{array}{l}\text { Proposed and adopt } \\
\text { wind load of } 240 \mathrm{Kg} / \mathrm{m}^{2} \\
\text { for girder bridge and } \\
360 \mathrm{Kg} / \mathrm{m}^{2} \text { for trusse } \\
\text { bridges. }\end{array}$ & \\
\hline 4 & $\begin{array}{l}\text { Temperature Variation for expansion joints } \\
\text { etc. } 6258 \mathrm{C}\end{array}$ & N.A. & Proposed & AASHTO 1977 \\
\hline
\end{tabular}




\section{LOADINGS FOR RURAL BRIDGES}

Nepal Road Standard incorporates the both AASHTO and IRC loadings. We have a separate standard for the rural roads, the Nepal Rural Roads Standard (NRSS 2055). The Nepal Rural Road Standard (NRSS) is not equivalent to the Nepal Road Standard. The NRSS covers the low volume and light vehicle standard rural roads more than $20,000 \mathrm{~km}$ in lengths. Hence, adaptation of NRS for bridge loadings may not be justified economically for rural roads and the rural bridges as the NRS loads are higher and this is suitable for highways and feeder roads.

Mostly the rural bridges have the short span decks. Individual truck loading may be relevant rather than the train of loading. Thus, the 24R IRC loading may be an appropriate loading for rural bridges. This represents a heavy vehicle plying in Nepalese roads.

\section{RECOMMENDATIONS}

The 24R IRC loading seems to be an appropriate loading for rural bridges in rural roads of Nepal. Hence the loading is recommended for consideration in design of rural bridges. This load represents a heavy vehicle (truck).

The recommended load consists of 20 tons loading with four wheels 8 tons in front axle and 12 tons in rear axle in $4.27 \mathrm{~m}$ distance in the first type of loading. In the second type of loading, in the same class of loading has 21.2 tons loading consisting of six wheels 4.2 tons in front axle, 8.5 tons in intermediate and rear axles. The distance between the front and intermediate axle is $3.96 \mathrm{~m}$ and the intermediate to the rear axle is $1.22 \mathrm{~m}$ as shown in the Figure 2. The spacing between successive vehicles can be assumed to be 30 m.
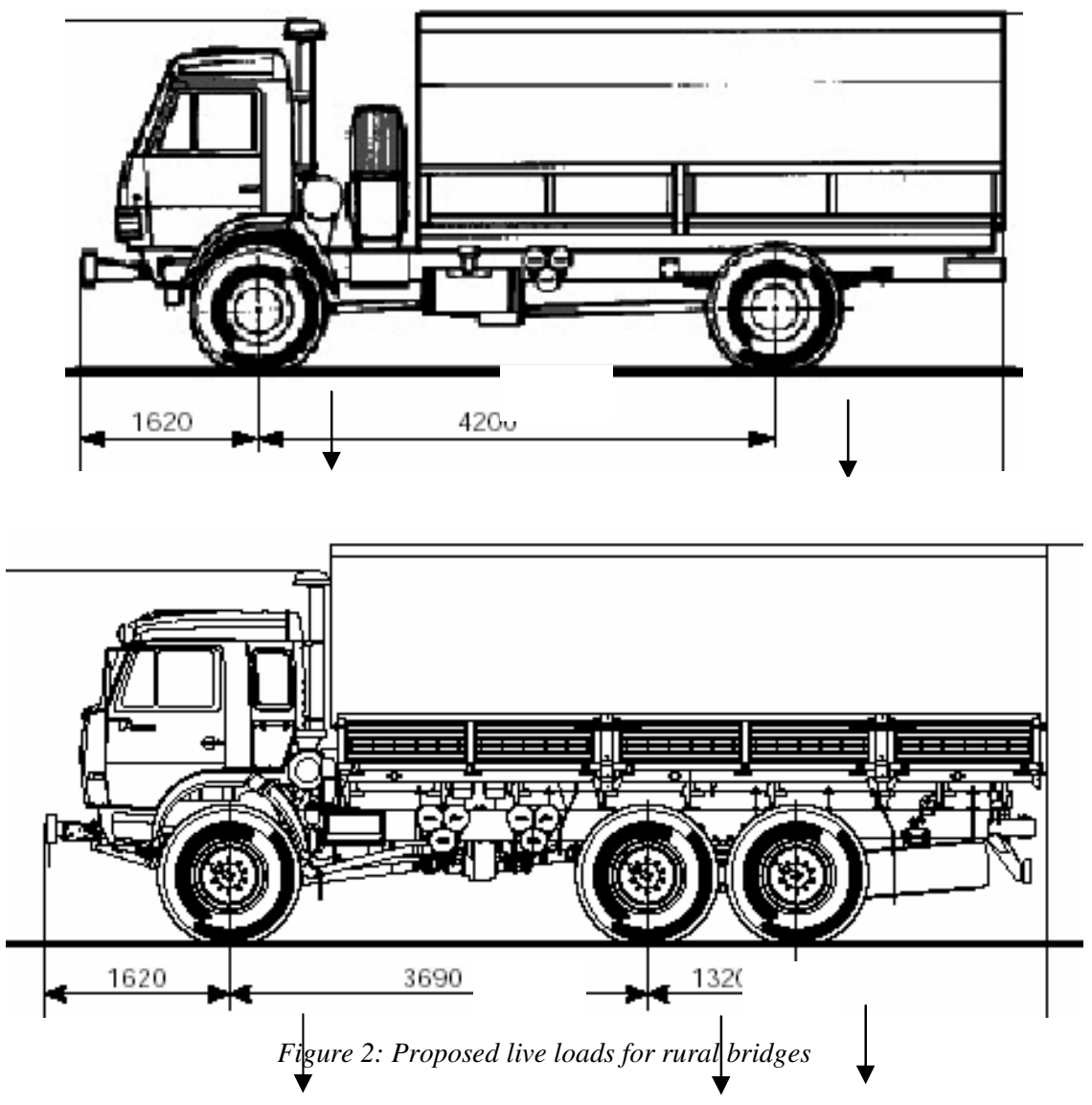


\section{REFERENCES}

[1] AASHTO, standard specification for design of highway bridges, Washington D.C., USA, 1992

[2] D. J. Victor, Essentials of Bridge Engineering, fifth edition, Oxford and IBH publishing Co. Pvt. Ltd., New Delhi, 2006

[3] IRC:6-2000, standard specification and code for practice for road bridges, Section II- loads and stresses, Indian Road Congress, 2000
[4] Nepal Road Standard 2027, Department of Roads, Ministry of Physical planning and Works, 2054.

[5] Nepal Rural Road Standard, 2055, DoLIDAR, Ministry of Local Development, 2055. 
